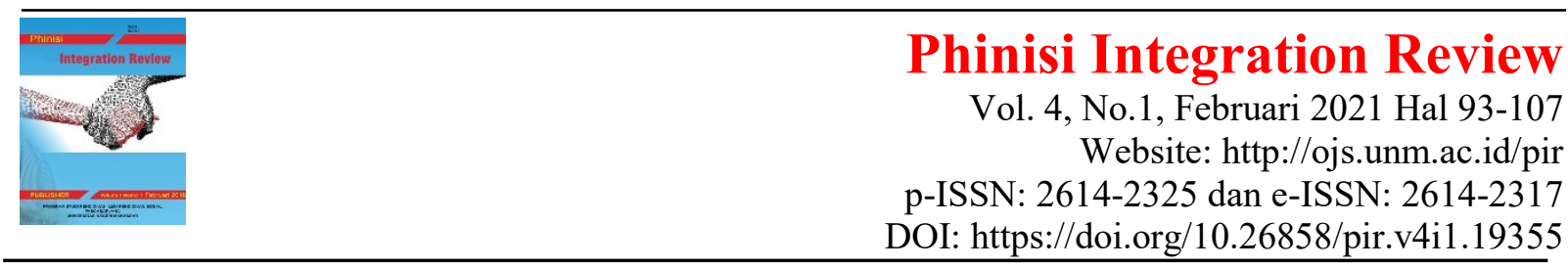

\title{
Menyusun Soal PKP-PKA Berstandar Adalah Keniscayaan
}

\author{
Budiman Tahir \\ BPSDM Provinsi Sulawesi Selatan, Indonesia \\ Email: budiman_tahir@yahoo.co.id
}

\begin{abstract}
Abstrak. Artikel ini didasari belum tuntasnya tugas widyaiswara melaksanakan tugas pokoknya dalam proses pembelajaran, yakni melaksanakan evaluasi pembelajaran. Tidak sedikit widyaiswara abai terhadap evaluasi pembelajaran, tidak membuat instrumen apatahlagi melaksanakan evaluasi pembelajaran. Bertujuan untuk mendeskripsikan cara menyusun kisi-kisi soal, menyusun soal PKP-PKA berstandar, dan menyusun soal PKPPKA berstandar secara online menggunalan aplikasi. Artikel ini merupakan kajian pustaka. Hasil pembahasan dinyatakan bahwa kriteria menyusun kisi-kisi soal meliputi: pemilihan sampel materi, jenis tes yang akan digunakan, dan jenjang kemampuan berpikir yang ingin diuji. Menyusun soal pilihan ganda atau uraian mengacu pada aspek: materi, konstruksi, dan bahasa. Membuat soal kuis menggunakan aplikasi, misalnya google form, dengan langkah-langkah: Buka Google Formulir, kemudian klik ikon Plus; Di bagian kanan atas, klik Setelan; Klik Kuis lalu Jadikan ini sebagai kuis; Opsional: Untuk mengumpulkan alamat email, klik Umum lalu kumpulkan alamat email; dan e) Klik Simpan.
\end{abstract}

Kata kunci: menyusun soal, berstandar, keniscayaan.

\begin{abstract}
This paper is based on the incomplete task of Widyaiswara in carrying out his main task in the learning process, namely carrying out a learning evaluation. Not a few widyaiswara ignore the evaluation of learning, do not make any other instruments to carry out learning evaluations. Aims to describe how to compile a grid of questions, compile standard PKP-PKA questions, and compile standard PKP-PKA questions online using an application. This paper is a literature review. The results of the discussion stated that the criteria for compiling the questionnaire included: selection of material samples, types of tests to be used, and levels of thinking skills to be tested. Compiling multiple choice questions or descriptions refers to the following aspects: material, construction, and language. Create a quiz question using an application, for example google form, with the following steps: Open Google Forms, then click the Plus icon; At the top right, click Settings; Click Quiz then Make it a quiz; Optional: To collect email addresses, click General and then collect email addresses; and e) Click Save.
\end{abstract}

Keywords: compiling questions, standardized, necessity.

Ini adalah artikel dengan akses terbuka dibawah licenci CC BY-NC-4.0

(https://creativecommons.org/licenses/by-nc/4.0/).

\section{PENDAHULUAN}

Salah satu persoalan penyelengaraan Pelatihan Kepemimpinan Aparatur (PKA) dan Pelatihan Kepemimpinan Pengawas (PKP) sebagai bentuk Pendidikan dan Pelatihan di lembaga kediklatan adalah belum tuntasnya widyaiswara dalam melaksanakan tugas pokoknya. Tugas pokok widyaiswara dalam pembelajaran (salah satu aspek dari Dikjartih) 
diawali dengan penyusunan program pembelajaran (membuat Rancanag Bangun Pembelajaran Mata Diklat disingkat RBPMD dan Remcana Pembelajaran disingkat RP), bahan tayang, bahan ajar, media pembelajaran, instrument evaluasi), yang dilanjutkan dengan pelaksanaan proses pembelajaran. Setelah pembelajaran dilakukan, maka dilaksanakan evaluasi pembelajaran.

Evaluasi pembelajaran menjadi momok, karena tidak sedikit widyaiswara abai terhadap evaluasi pembelajaran. Hasil diskusi dengan teman widyaiswara bahwa sebagian dari mereka tidak membuat instrument evaluasi pembelajaran apatahlagi melaksanakan evaluasi pembelajaran.

Beberapa kesulitan yang dihadapi widyaiswara adalah pada saat penyusunan perangkat tes. Beberapa widyaiswara merasa kerepotan dalam menyusun kartu soal, sehingga seringkali kartu soal diabaikan. Kesulitan yang dihadapi widyaiswara lainnya adalah analisis peserta pelatihan dan butir soal. Walaupun sesungguhnya, banyak widyaiswara yang sudah menggunakan Ms. Excel, tetapi kebanyakan belum menggunakan program secara berkelanjutan, sehingga penggunaan program belum optimal.

Pramana, Supraptono, \& Pribadi (2013) dalam jurnalnya menyatakan bahwa melakukan analisis butir soal menjadi sebuah kegiatan yang wajib bagi pendidik, termasuk widyaiswara. Hal tersebut dikarenakan widyaiswara harus mampu menyajikan informasi, baik kepada lembaga maupun kepada peserta diklat. Informasi yang dihadirkan antara lain: penguasaan peserta diklat terhadap materi hingga keterampilan yang telah dicapai..

Kurang optimalnya pengunaan teknologi menjadi salah satu sebab belum maksimalnya widyaiswara dalam melengkapi perangkat penilaian usai pembelajarannya, termasuk pasca diklat. Jika mampu mengelola teknologi dengan baik, akan memudahkan widyaiswara, bahkan lembaga diklat, dalam melakukan evaluasi dan menindaklanjuti hasilnya.

Manajemen Mutu telah merancang dan menerapkan Excel-based Workbook For Quality Management (EWQM) sudah lebih dari satu dekade. EWQM digunakan utuk layanan akademik, sekaligus sebagai sarana mengukur kualitas dan produktivitas bidang akademik ditingkat universitas. Sistem ini mengintegrasikan informasi yang lebih lengkap, akurat, tepat dan dapat diandalkan. Dalam prosesnya, EWQM mampu menghitung kualitas dan produktivitas indeks untuk setiap bidang akademis dan memberikan umpan balik kepada top management tentang segala sesuatu yang harus dipertimbangkan dalam rencana perbaikan yang terus-menerus.

Tujuan dari penulisan makalah ini adalah: (1) Untuk mendeskripsikan cara menyusun kisikisi soal PKP-PKA berstandar; (2) Untuk mendeskripsikan cara menyusun soal sesuai kisikisi soal PKP-PKA berstandar; (3) Untuk mendeskripsikan cara menyusun soal PKP-PKA berstandar secara online menggunalan aplikasi.

\section{METODE}

Metode penelitian yang digunakan dalam penelitian ini merupakan penelitian kepustakaan (Library Research) atau Kajian Pustaka. Kajian pustaka dapat diartikan sebagai rangkaian kegiatan pengumpulan data melalui mencatat, membaca, dan mengolah bahan penelitian (Zed, 2003). Penggalian beragam informasi kepustakaan bisa dilakukan melalui jurnal ilmiah, buku, dokumen, ensiklopedia, surat kabar, majalah. Penelitian kepustakan ini secara kritis mengkaji pengetahuan, ide, atau penemuan yang terkandung dalam karya sastra berorientasi akademik dan menguraikan kontribusi teoritis dan metodologisnya pada topik tertentu (Syaodih, 2009)

\section{HASIL DAN PEMBAHASAN}

\section{A. Evaluasi Peserta Pelatihan Kepemimpinan Pengawas dan Administrator}

Berdasarkan Peraturan Kepala LAN Nomor 15 Tahun 2019 tentang Pelatihan Kepemimpinan Pengawas dan Peraturan Kepala LAN Nomor 15 Tahun 2019 tentang Pelatihan Kepemimpinan Administrator bahwa evalusi PKP dan PKA dilaksanakan oleh LAN atau Lembaga Pelatihan Terakreditasi.

Evaluasi PKP dan PKA terdiri atas: 1) evaluasi Peserta; 2) evaluasi tenaga pelatihan; 3) evaluasi penyelenggaraan; dan 4) evaluasi pasca pelatihan. Evaluasi Peserta dilaksanakan untuk menilai pencapaian Kompetensi kepemimpinan melayani dan kepemimpinanmanajemen kinerja.

Evaluasi tenaga pelatihan dilaksanakan untuk menilai kemampuan tenaga pelatihan dalam melaksanakan tugasnya. Evaluasi penyelenggaraan dilaksanakan untuk menilai kualitas pelayanan penyelenggaraan PKP dan KPA. Evaluasi pasca pelatihan dilaksanakan 
untuk mengetahui dan menilai kesinambungan Aksi Perubahan di tempat kerja.

Evaluasi Peserta meliputi: evaluasi substansi, evaluasi studi lapangan, evaluasi Aksi Perubahan; dan evaluasi sikap perilaku. Berdasarkan hasil evaluasi peserta dilakukan evaluasi akhir Peserta. Penilaian evaluasi Peserta sebagaimana dilakukan dengan menggunakan sistem penilaian (scoring) dalam rentang nilai 0 (nol) sampai dengan 100 (seratus). Bagi Peserta yang memperoleh nilai kurang dari 70 (tujuh puluh) untuk jenis evaluasi diberikan 1 (satu) kali kesempatan untuk melakukan remedial. Remedial dilaksanakan sebelum PKP berakhir.

Evaluasi substansi diberikan untuk mata pelatihan yang terdapat pada agenda 2 dan agenda 3, baik Pelatihan Kepemimpinan Pengawas maupun Pelatihan Kepemimpinan Administrator. Untuk pelatihan kepemimpinan pengawas, mata pelatihan yang dibuatkan evaluasi substansi agenda 2 kepemimpinan pelayanan, adalah: diagnosa organisasi, berpikir kreatif dalam pelayanan, membangun tim efektif, dan kepemimpinan dalam pelaksanaan pekerjaan; dan mata pelatihan yang dibuatkan evaluasi substansi untuk agenda 3 pengendalian pekerjaan, adalah: teknik komunikasi publik, perencanaan kegiatan pelayanan publik, penyusunan RKA pelayanan publik, pelayanan publik digital, manajemen mutu, manajamen pengawasan, dan pengendalian pelaksanaan pekerjaan.

Untuk pelatihan kepemimpinan administrator, mata pelatihan yang dibuatkan evaluasi substansi agenda 2 kepemimpinan kinerja, adalah: manajemen perubahan sektor publik; manajemen transformasional, dan jejaring kerja; dan mata pelatihan yang dibuatkan evaluasi substansi untuk agenda 3 manajemen kinerja, adalah: akuntabilitas kinerja, hubungan kelembagaan, organisasi digital, manajemen kinerja, standar kinerja pelayanan, manajemen penganggaran, dan manajemen risiko.

\section{B. Deskripsi Cara Menyusun Kisi-Kisi Soal PKP-PKA Berstandar}

\section{Teknik Menyusun Kisi-Kisi Soal}

Beberapa hal penting yang harus diperhatikan dalam menyusun kisi-kisi antara lain: a. Pemilihan sampel materi yang akan ditulis butir soalnya hendaknya dilakukan dengan mengacu pada tujuan pembelajaran atau kompetensi yang ingin dicapai. Pilihlah sampel materi yang secara representatif dapat mewakili semua materi yang telah diajarkan selama proses pembelajaran. Semakin banyak sampel materi yang dapat ditanyakan maka semakin banyak pula tujuan pembelajaran yang akan dapat kita ukur. Dasar pertimbangan yang dipergunakan dalam pemilihan sampel materi adalah dasar pertimbangan keahlian (expert judgement).

b. Jenis tes yang akan digunakan. Pemilihan jenis tes yang akan digunakan berhubungan erat dengan jumlah sampel materi yang dapat diukur, tingkat kognitif yang akan diukur, jumlah peserta tes, serta jumlah butir soal yang akan dibuat. Ada dua jenis tes yang dapat dipergunakan sebagai alat ukur hasil belajar peserta, yaitu tes objektif dan tes uraian. Pemilihan jenis tes sangat terkait dengan tujuan pembelajaran yang akan di ukur. Jika tujuan pembelajaran yang akan diukur lebih banyak pada proses berpikir rendah dan sedang maka jenis tes objektif lebih tepat menjadi pilihan utama. Tetapi jika tujuan pembelajaran yang akan diukur lebih banyak pada proses berpikir tinggi seperti analisis, evaluasi, dan kreasi, maka jenis tes uraian merupakan alat ukur yang tepat. Pemilihan jenis tes ini juga akan berhubungan erat dengan jumlah butir soal yang akan diujikan.

c. Jenjang kemampuan berpikir yang ingin diuji. Setiap mata pelatihan mempunyai penekanan kemampuan yang berbeda dalam mengembangkan proses berpikir peserta. Dengan demikian jenjang kemampuan bepikir yang akan diuji pun berbeda-beda. Jika tujuan suatu mata pelatihan lebih menekankan pada pengembangan proses berpikir analisis, evaluasi, dan kreasi, maka butir soal yang akan digunakan dalam ujian harus dapat mengukur kemampuan tersebut demikian juga sebaliknya. Secara singkat dapat dikatakan bahwa kumpulan butir soal yang akan digunakan dalam ujian harus dapat mengukur proses berpikir yang relevan dengan proses berpikir yang dikembangkan selama proses pembelajaran. Dalam hubungan ini kita mengenal ranah kognitif yang dikembangkan oleh Bloom dan kawankawan yang kemudian direvisi oleh Krathwoll (2001). Revisi Krathwoll terhadap 
tingkatan dalam ranah kognitif adalah ingatan $(\mathrm{C} 1)$, pemahaman $(\mathrm{C} 2)$, penerapan (C3), analisis (C4), evaluasi (C5), dan kreasi (C6).

Berikut ini akan diuraikan secara singkat ke6 jenjang proses berpikir tersebut:

1) Ingatan (C1), merupakan jenjang proses berpikir yang paling sederhana. Butir soal akan dikatakan mengukur kemampuan proses berpikir ingatan, jika butir soal tersebut hanya meminta pada peserta pelatihan untuk mengingat kembali tentang segala sesuatu yang telah diajarkan dalam proses pembelajaran, seperti mengingat nama, istilah, rumus, gejala, dan sebagainya tanpa menuntut kemampuan untuk memahami atau menggunakannya.

2) Pemahaman (C2), merupakan jenjang proses berpikir yang setingkat lebih tinggi dari ingatan. Butir soal dikatakan mengukur kemampuan proses berpikir pemahaman, jika butir soal tersebut tidak hanya meminta pada peserta pelatihan untuk mengingat kembali tentang segala sesuatu yang telah diajarkan dalam proses pembelajaran, tetapi peserta pelatihan tersebut harus mengerti, dapat menangkap arti dari materi yang dipelajari serta dapat melihatnya dari beberapa segi.

3) Penerapan (C3), merupakan jenjang proses berpikir yang setingkat lebih tinggi dari pemahaman. Butir soal dikatakan mengukur kemampuan proses berpikir penerapan jika butir soal tersebut meminta pada peserta pelatihan untuk memilih, menggunakan, atau menggunakan dengan tepat suatu rumus, metode, konsep, prinsip, hukum, teori, atau dalil jika dihadapkan pada situasi baru.

4) Analisis (C4), merupakan jenjang proses berpikir yang setingkat lebih tinggi dari penerapan. Butir soal dikatakan mengukur kemampuan proses berpikir analisis jika butir soal tersebut meminta pada peserta pelatihan untuk merinci atau menguraikan suatu bahan atau keadaan menurut bagianbagian yang lebih kecil dan mampu memahami hubungan antarbagian tersebut.

5) Evaluasi (C5), merupakan jenjang proses berpikir yang lebih kompleks dari analisis. Butir soal dikatakan mengukur kemampuan proses berpikir evaluasi jika butir soal tersebut meminta pada peserta pelatihan untuk membuat pertimbangan atau menilai terhadap sesuatu berdasarkan kriteria-kriteria yang ada.

6) Kreasi (C6), merupakan jenjang proses berpikir yang paling kompleks. Proses berpikir ini menghendaki peserta pelatihan untuk menghasilkan suatu produk yang baru sebagai hasil kreasinya.

d. Sebaran tingkat kesukaran butir soal. Dalam menentukan sebaran tingkat kesukaran butir soal dalam set soal untuk ujian harus mempertimbangkan interpretasi hasil tes mana yang akan dipergunakan. Ada dua pendekatan yang dapat digunakan dalam menginterpretasikan hasil tes. Pertama pendekatan Penilaian Acuan Kriteria atau Patokan (PAK atau PAP) dan kedua adalah pendekatan Penilaian Acuan Norma (PAN). Pembahasan lebih detail tentang kedua pendekatan ini akan dibahas dalam modul berikutnya. Karena dalam program PJJ interpretasi hasil tes yang digunakan berbasis kompetensi, maka pendekatan yang digunakan adalah PAK. Sehingga dalam menginterpretasikan hasil tes yang menjadi pertimbangan dalam penyusunan butir soal ujian adalah ketercapaian tujuan yang telah ditetapkan dalam pembelajaran. Walaupun butir soal itu mudah tetapi kalau butir soal tersebut diperlukan untuk mengukur tujuan yang telah ditetapkan, maka butir soal tersebut harus digunakan.

e. Waktu yang disediakan untuk pelaksanaan ujian. Lamanya waktu ujian merupakan faktor pembatas yang harus diperhatikan dalam membuat perencanaan tes. Lamanya waktu ujian (misalnya 90 menit) akan membawa konsekuensi kepada banyaknya butir soal yang harus dibuat. Jumlah butir soal yang akan diujikan harus diperkirakan agar dapat diselesaikan dalam dalam waktu 90 menit. Jumlah butir soal tidak boleh terlalu banyak atau terlalu sedikit. Jika butir soal yang disediakan terlalu banyak maka set soal 
Tahir. Menyusun Soal PKP-PKA Berstandar Adalah Keniscayaan ...

tersebut tidak akan dapat diselesaikan dalam waktu 90 menit. Jika ini terjadi maka akan mendorong kepada peserta pelatihan untuk menjawab butir soal dengan cara menebak, walaupun sebenarnya mereka dapat mengerjakan apabila disediakan waktu yang cukup. Sebaliknya, jika butir soal yang disediakan terlalu sedikit maka butir soal akan diselesaikan sebelum waktunya habis sehingga pelaksanaan ujian tidak efektif.

f. Jumlah butir soal. Penentuan jumlah butir soal yang tepat dalam satu kali ujian tergantung pada beberapa hal, antara lain: tujuan pembelajaran yang ingin dicapai, ragam soal yang akan digunakan, proses berpikir yang ingin diukur, dan se- baran tingkat kesukaran dalam set tes tersebut. Untuk waktu ujian 90 menit, jumlah butir soal objektif yang perlu dibuat kurang lebih 30 butir soal (untuk mata pelatihan yang banyak hitungan) dan 50 butir soal untuk mata pelatihan yang tidak banyak hitungan. Jika Anda memilih tes uraian, maka Anda perlu menulis 4 - 5 butir soal. Jika tujuan pembelajaran yang akan Anda ukur tersebar mulai dari proses berpikir rendah sampai dengan berpikir tinggi, Anda dapat menggunakan gabungan antara tes pilihan ganda dan tes uraian.

\section{Lembar Indikator Soal}

Untuk membantu mempermudah pengisian format kisi-kisi, lakukan langkah-langkah berikut:

a. Siapkan format kisi-kisi dan buku materi yang akan Anda gunakan sebagai sumber dalam pembuatan kisikisi.

b. Tentukan kompetensi dasar dan indikator pembelajaran yang akan diukur. Kompetensi dasar dan indikator pembelajaran dapat Anda ambil dari Modul Elektronik (ME). Dalam ME, kompetensi dasar dijabarkan ke dalam indikator pembelajaran yang biasanya hanya ditulis indikator pembelajaran yang esensial saja. Jika Anda menganggap ada indikator pembelajaran yang penting untuk diukur tetapi tidak ditulis dalam ME, Anda dapat mengukurnya dalam ujian sepanjang materi dalam ME dapat mencapai indikator pembelajaran tersebut.

c. Tentukan pokok bahasan dan subpokok bahasan yang akan digunakan untuk mengukur ketercapaian indikator pembelajaran tersebut. Kemudian tuliskan pokok bahasan dan sub-pokok bahasan tersebut pada lembar kisi-kisi. Upayakan pokok bahasan dan sub pokok bahasan tersebut merupakan sampel materi yang representatif mewakili keseluruhan materi dalam ME.

d. Tentukan berapa jumlah butir soal yang layak ditanyakan dalam satu waktu ujian tersebut. Penentuan jumlah butir soal harus memperhatikan tingkat kesukaran butir soal dan proses berpikir yang ingin diukur

e. Sebarkan jumlah butir soal tersebut per pokok bahasan. Penentuan jumlah butir soal per pokok bahasan hendaknya dilakukan secara proporsional berdasarkan kepentingan atau keluasan pokok bahasan. Jadi jumlah butir soal per pokok bahasan tidak harus sama

f. Distribusikan jumlah butir soal per pokok bahasan tersebut ke dalam subpokok bahasan sub-pokok bahasan. Pendistribusian jumlah butir soal ini juga harus dilakukan secara proporsional sesuai dengan kepentingan atau keluasan sub-pokok bahasan tersebut

g. Distribusikan jumlah butir soal per subpokok bahasan tersebut ke dalam kolom-kolom proses berpikir dan tingkat kesukaran butir soal. Pendistribusian ini harus berpedoman pada tujuan pembelajaran yang akan diukur ketercapaiannya dan proses berpikir yang dikembangkan selama proses pembelajaran

Setelah selesai mengembangkan kisi-kisi, langkah selanjutnya adalah menulis lembar indikator soal dengan menggunakan format di bawah ini. Hal ini dimaksudkan agar penulis butir soal dapat menulis soal sesuai dengan harapan penulis kisi-kisi. Indikator soal ditulis dalam format sebagai berikut. 


\section{Deskripsi Cara Menyusun Soal Sesuai Kisi-Kisi Soal PKP-PKA Berstandar}

\section{Penulisan Soal Pilihan Ganda}

Tes objektif jenis pilihan ganda ini merupakan jenis tes objektif yang paling banyak digunakan. Konstruksi tes pilihan ganda terdiri atas dua bagian, yaitu pokok soal (stem) dan alternatif jawaban (option). Satu di antara alternatif jawaban tersebut adalah jawaban yang benar atau yang paling benar (kunci jawaban), sedangkan alternatif jawaban yang lain berfungsi sebagai pengecoh (distractor).

Pokok soal dapat dibuat dalam dua bentuk, yaitu dalam bentuk pernyataan tidak selesai atau dalam bentuk kalimat tanya. Jumlah alternatif jawaban yang dibuat biasanya empat atau lima. Semakin banyak alternatif jawaban yang dibuat, maka probabilitas peserta untuk menebak jawaban semakin kecil. Tata tulis tes pilihan ganda diatur sebagai berikut. Jika pokok soal (stem) ditulis dengan kalimat tidak selesai, maka awal kalimat ditulis dengan huruf besar dan awal option ditulis dengan huruf kecil (kecuali untuk nama diri atau nama tempat).

Karena pokok soal ditulis dengan kalimat tidak selesai, maka pada akhir kalimat disertai dengan empat buah titik. Tiga buah titik yang pertama adalah titik-titik untuk pokok soal yang ditulis dengan kalimat tidak selesai dan satu titik yang terakhir merupakan titik akhir alternatif jawaban. Dengan demikian akhir setiap alternatif jawaban tidak perlu diberi tanda titik. berikut ini.

Perhatikanlah struktur tes pilihan ganda

\section{berikut ini.}

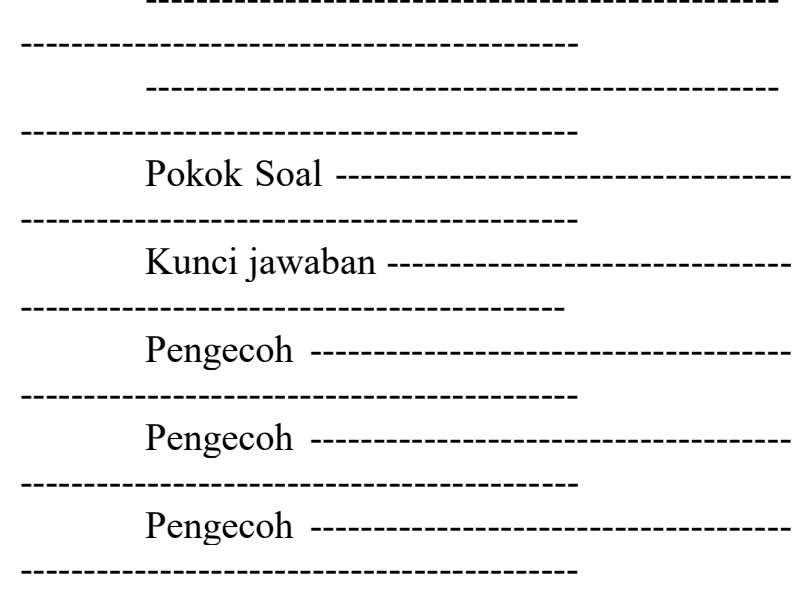

Jika pokok kalimat ditulis dengan kalimat tanya, maka awal kalimat ditulis dengan huruf kapital dan akhir kalimat diberi tanda tanya. Setiap awal option dimulai dengan huruf kapital dan diakhiri dengan tanda titik. Dengan demikian konstruksi tes pilihan ganda dapat ditulis sebagai berikut.

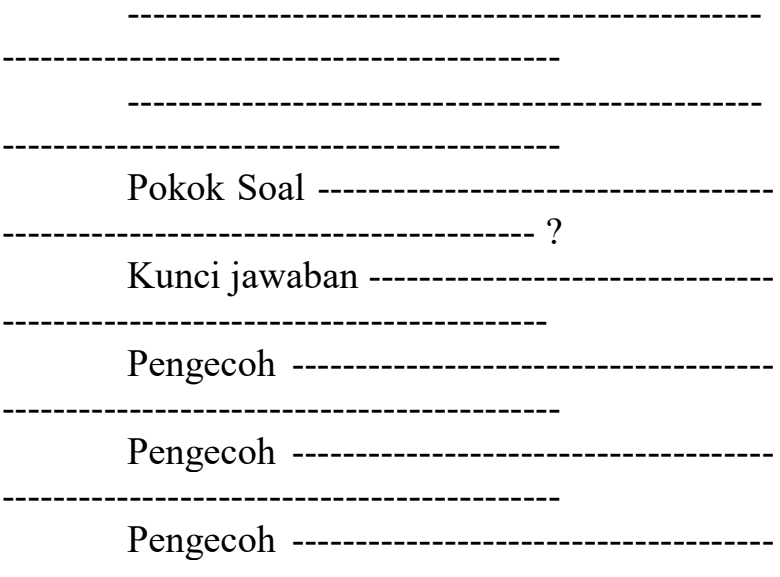

\section{Bagaimana menulis tes pilihan ganda yang baik ?}

Kaidah penulisan soal pilihan ganda adalah seperti berikut ini.

\section{Materi}

a. Soal harus sesuai dengan indikator. Artinya soal harus menanyakan perilaku dan materi yang hendak diukur sesuai dengan rumusan indikator dalam kisikisi.

b. Pengecoh harus bertungsi

c. Setiap soal harus mempunyai satu jawaban yang benar. Artinya, satu soal hanya

\section{Konstruksi} mempunyai satu kunci jawaban.

a. Pokok soal harus dirumuskan secara jelas dan tegas. Artinya, kemampuan/ materi yang hendak diukur/ditanyakan harus jelas, tidak menimbulkan pengertian atau penafsiran yang berbeda dari yang dimaksudkan penulis. Setiap butir soal hanya mengandung satu persoalan/gagasan

b. Rumusan pokok soal dan pilihan jawaban harus merupakan pernyataan yang diperlukan saja. Artinya apabila terdapat rumusan atau pernyataan yang sebetulnya tidak diperlukan, maka rumusan atau pernyataan itu dihilangkan saja.

c. Pokok soal jangan memberi petunjuk ke arah jawaban yang benar. Artinya, pada pokok soal jangan sampai terdapat kata, 
kelompok kata, atau ungkapan yang dapat memberikan petunjuk ke arah jawaban yang benar.

d. Pokok soal jangan mengandung pernyataan yang bersifat negatif ganda. Artinya, pada pokok soal jangan sampai terdapat dua kata atau lebih yang mengandung arti negatif. Hal ini untuk mencegah terjadinya kesalahan penafsiran peserta didik terhadap arti pernyataan yang dimaksud. Untuk keterampilan bahasa, penggunaan negatif ganda diperbolehkan bila aspek yang akan diukur justru pengertian tentang negatif ganda itu sendiri.

e. Pilihan jawaban harus homogen dan logis ditinjau dari segi materi. Artinya, semua pilihan jawaban harus berasal dari materi yang sama seperti yang ditanyakan oleh pokok soal, penulisannya harus setara, dan semua pilihan jawaban harus berfungsi.

f. Panjang rumusan pilihan jawaban harus relatif sama. Kaidah ini diperlukan karena adanya kecenderungan peserta didik memilih jawaban yang paling panjang karena seringkali jawaban yang lebih panjang itu lebih lengkap dan merupakan kunci jawaban.

g. Pilihan jawaban jangan mengandung pernyataan "Semua pilihan jawaban di atas salah"atau "Semua pilihan jawaban di atas benar". Artinya dengan adanya pilihan jawaban seperti ini, maka secara materi pilihan jawaban berkurang satu karena pernyataan itu bukan merupakan materi yang ditanyakan dan pernyataan itu menjadi tidak homogen.

h. Pilihan jawaban yang berbentuk angka atau waktu harus disusun berdasarkan urutan besar kecilnya nilai angka atau kronologis. Artinya pilihan jawaban yang berbentuk angka harus disusun dari nilai angka paling kecil berurutan sampai nilai angka yang paling besar, dan sebaliknya. Demikian juga pilihan jawaban yang menunjukkan waktu harus disusun secara kronologis. Penyusunan secara unit dimaksudkan untuk memudahkan peserta didik melihat pilihan jawaban.

i. Gambar, grafik, tabel, diagram, wacana, dan sejenisnya yang terdapat pada soal harus jelas dan berfungsi. Artinya, apa saja yang menyertai suatu soal yang ditanyakan harus jelas, terbaca, dapat dimengerti oleh peserta didik. Apabila soal bisa dijawab tanpa melihat gambar, grafik, tabel atau sejenisnya yang terdapat pada soal, berarti gambar, grafik, atau tabel itu tidak berfungsi.

j. Rumusan pokok soal tidak menggunakan ungkapan atau kata yang bermakna tidak pasti seperti: sebaiknya, umumnya, kadang-kadang.

k. Butir soal jangan bergantung pada jawaban soal sebelumnya. Ketergantungan pada soal sebelumnya menyebabkan peserta didik yang tidak dapat menjawab benar soal pertama tidak akan dapat menjawab benar soal berikutnya.

\section{Bahasa/budaya}

a. Setiap soal harus menggunakan bahasa yang sesuai dengan kaidah bahasa Indonesia. Kaidah bahasa Indonesia dalam penulisan soal di antaranya meliputi: a) pemakaian kalimat: (1) unsur subyek, (2) unsur predikat, (3) anak kalimat; b) pemakaian kata: (1) pilihan kata, (2) penulisan kata, dan c) pemakaian ejaan: (1) penulisan huruf, (2) penggunaan tanda baca.

b. Bahasa yang digunakan harus komunikatif, sehingga pernyataannya mudah dimengerti warga belajar/peserta didik.

c. Pilihan jawaban jangan yang mengulang kata/frase yang bukan merupakan satu kesatuan pengertian. Letakkan kata/frase pada pokok soal.

\section{Penulisan Soal Uraian}

Berdasarkan jenis jawaban yang diberikan peserta pelatihan, Gronlund \& Linn (1990) mengelompokkan tes uraian dalam dua kelompok, yaitu tes uraian terbuka (Extended Response Question) dan tes uraian terbatas (Restricted Response Question). Yang dimaksud dengan tes uraian terbuka adalah tes uraian yang dapat dijawab dengan benar oleh peserta dari berbagai sudut pandang. Dengan demikian jawaban yang benar dari tes uraian terbuka lebih dari satu. Sedangkan yang dimaksud dengan tes uraian terbatas adalah suatu jenis tes uraian yang jawabannya sudah diarahkan ke jawaban tertentu. 


\section{Bagaimana menulis tes uraian yang baik?}

Ada dua hal pokok yang harus diperhatikan untuk mengembangkan tes uraian yang baik. Pertama, bagaimana cara menulis atau mengkonstruksi tes uraian agar dapat mengukur tujuan yang ingin diukur. Kedua, bagaimana kita dapat membuat pedoman penskoran yang baik.

Beberapa hal yang perlu diperhatikan pada saat mengkonstruksi tes uraian antara lain:

a. Tulislah tes uraian berdasarkan perencanaan tes yang telah dibuat.

b. Gunakan tes uraian untuk mengukur hasil belajar yang sukar atau tidak tepat jika diukur dengan tes objektif. Pada bagian depan dari pembahasan ini telah dijelaskan bahwa tes objektif kurang tepat, jika digunakan untuk mengukur hasil belajar pada jenjang atau proses berpikir tinggi seperti analisis, evaluasi, dan kreasi. Jika dikonstruksi dengan baik sebenarnya tes objektif juga dapat digunakan untuk mengukur jenjang berpikir tinggi, tetapi pada umumnya kita masih menemui kesulitan untuk menulis tes objektif seperti itu (Zainul dan Nasoetion, 1997). Salah satu keunggulan tes uraian, jika dibandingkan dengan tes objektif adalah tes uraian lebih tepat digunakan untuk mengukur tujuan pembelajaran yang ingin mengembangkan proses berpikir tinggi. Untuk itu tes uraian tidak disarankan untuk digunakan mengukur proses berpikir rendah, seperti ingatan atau pemahaman.

c. Untuk membantu dalam membuat tes uraian, agar dapat mengukur jenjang berpikir tinggi, kembangkanlah butir soal tersebut dari suatu kasus. Dari kasus tersebut tuliskan beberapa pertanyaan yang diinginkan.

d. Gunakan tes uraian terbatas. Ada beberapa keuntungan yang dapat diperoleh dengan menggunakan tes uraian terbatas.

Pertama, memperkecil kemungkinan salah penafsiran terhadap maksud pertanyaan yang ada pada butir soal. Dengan menggunakan tes uraian terbatas peserta akan lebih cepat menangkap apa yang dimaksud dengan pertanyaan dalam butir soal dan ke arah mana ia harus menjawab pertanyaan tersebut.

Kedua, sampel materi yang dapat ditanyakan dalam satu waktu ujian akan lebih banyak, jika dibandingkan dengan menggunakan tes uraian terbuka. Dengan meningkatnya sampel materi yang dapat ditanyakan, maka validitas isi tes semakin dapat dipertanggungjawabkan.

Ketiga, dengan menggunakan tes uraian terbatas maka kita akan lebih mudah memeriksa jawaban peserta karena jawaban peserta sudah terarah.

Keempat, dengan menggunakan tes uraian terbatas, kita akan dapat memberikan skor yang lebih objektif dan konsisten untuk setiap jawaban peserta.

e. Usahakan agar pertanyaan yang diberikan mengungkap pendapat peserta bukan hanya sekedar menyebutkan fakta.

Untuk itu gunakan kata-kata tanya seperti jelaskan, bandingkan, hubungkan, simpulkan, analisislah, kelompokkanlah, identifikasikanlah, dan sebagainya. Hindarkan penggunaan kata tanya seperti: sebutkan, karena penggunaan kata tanya seperti itu hanya akan meminta kepada peserta untuk menyebutkan fakta bukan mengungkapkan pendapat.

f. Rumuskan pertanyaan dengan jelas dan tegas sehingga tidak menimbulkan salah tafsir bagi peserta.

g. Rancanglah sejumlah pertanyaan yang memang dapat dikerjakan oleh peserta dalam satu waktu ujian yang telah Anda tentukan. Kejadian yang sering terjadi adalah peserta belum dapat menyelesaikan seluruh butir soal, tetapi waktu mengerjakan sudah habis. Agar hal tersebut tidak terjadi, maka pada saat menyusun tes uraian perlu mempertimbangkan kemampuan dan kecepatan menulis dari para peserta.

h. Hindari penggunaan pertanyaan pilihan. Yang dimaksud dengan menggunakan pertanyaan pilihan adalah menyediakan sejumlah pertanyaan kemudian peserta diberi kebebasan untuk mengerjakan beberapa butir pertanyaan saja. 
Misalkan disediakan 8 butir pertanyaan kemudian peserta diminta untuk mengerjakan 5 dari 8 butir pertanyaan tersebut. Bagi peserta, hal tersebut sangat menguntungkan karena mereka dapat memilih pertanyaan mana yang dapat dijawab dengan baik. Tetapi para ahli pengukuran seperti Gronlund \& Linn (1990), Nitko (1984), Hopkins \& Antes (1990), dan lainnya tidak menyarankan penggunaan pertanyaan pilihan tersebut. Alasan yang dikemukakan adalah jika peserta mengerjakan tes yang berbeda berarti kemampuan peserta diukur dengan menggunakan alat ukur yang berbeda. Dengan demikian kesamaan alat ukur untuk menilai hasil belajar setiap peserta tidak ada.

i. Pada setiap butir soal, tuliskan skor maksimal yang dapat diperoleh peserta apabila ia dapat mengerjakan butir soal tersebut dengan baik. Hal ini penting bagi peserta untuk memprediksi skor yang diperoleh setelah ia mengerjakan keseluruhan tes tersebut.

Beberapa hal yang perlu Anda perhatikan dalam membuat pedoman penskoran adalah:

a. Tuliskan jawaban terbaik dari butir soal tersebut!

b. Jika ada alternatif jawaban yang lain dari pertanyaan tersebut maka alternatif jawaban tersebut harus ditulis.

c. Butir atau konsep atau kata kunci apa yang harus ada pada jawaban tersebut?

d. Adakah butir atau konsep atau kata kunci yang menurut pertimbangan Anda mempunyai bobot yang lebih dari butir atau konsep atau kata kunci yang lain?

e. Berikan skor pada setiap butir atau konsep atau kata kunci yang Anda harapkan.

f. Butir atau konsep atau kata kunci yang Anda anggap mempunyai bobot lebih dari yang lain dapat diberi skor lebih tinggi.

g. Cantumkan jumlah skor maksimal pada bagian kanan atas setiap butir
D. Deskripsi Cara Menyusun Soal PKP-PKA Berstandar secara Online Menggunakan Aplikasi

\section{Menyusun Soal Menggunakan Google Form}

Salah satu dampak pandemi COVID-19 adalah perubahan sistem pelatihan menjadi via daring. Bagi kebanyakan lembaga diklat, pelatihan ini masih harus menyesuaikan banyak hal, termasuk cara melatih peserta pelatihan menjawab soal-soal tanpa mereka harus menyontek dengan membuka internet. Bagaimana cara yang bisa dipakai widyaiswara untuk membuat soal daring dengan tetap menjaga peserta pelatihan tidak menyontek? Google Form menyediakan konsep pembelajaran demikian.

Google menjelaskan bahwa kita dapat membuat, mengirim, dan menilai kuis dengan Google Formulir.

a. Cara membuat soal kuis menggunakan Google Form

1) Buka Google Formulir, kemudian klik ikon Plus.

2) Di bagian kanan atas, klik Setelan.

3) Klik Kuis lalu Jadikan ini sebagai kuis.

4) Opsional: Untuk mengumpulkan alamat email, klik Umum lalu kumpulkan alamat email.

5) Klik Simpan.

b. Cara membuat kunci jawaban, menetapkan poin (nilai) dan menambahkan masukan otomatis. Kita dapat membuat kunci jawaban untuk jenis soal jawaban singkat, pilihan ganda, kotak centang, dropdown, petak pilihan ganda dan petak kotak centang. Berikut cara membuat kunci jawaban:

1) Untuk menambahkan pertanyaan, klik tambahkan pertanyaan.

2) Isikan pertanyaan dan jawaban Anda.

3) Di kiri bawah pertanyaan, klik kunci jawaban. - Pilih jawaban atau jawaban yang benar.

4) Di kanan atas pertanyaan, pilih berapa poin nilai pertanyaan tersebut.

5) Opsional: Untuk menambahkan penjelasan tertulis atau video YouTube ke sebuah jawaban, klik tambahkan masukan jawaban. 
6) Opsional: Untuk mengedit opsi pertanyaan atau jawaban, klik edit pertanyaan. Catatan: Anda dapat menetapkan poin dan menambahkan masukan pada semua jenis pertanyaan.

c. Cara memilih tampilan selama dan setelah kuis. Seseorang melihat pertanyaan yang tidak terjawab, jawaban yang benar, dan berapa nilai dari soal itu, caranya sebagai berikut:

1) Di Google Formulir, buka kuis.

2) Di bagian kanan atas, klik setelan.

3) Klik kuis.

4) Di bagian "Responden dapat melihat", centang kotaknya.

d. Menggunakan mode terkunci untuk kuis. Kita dapat membantu peserta pelatihan tetap fokus saat mengikuti kuis dan ujian di Chromebook-nya. Saat peserta pelatihan mengikuti kuis dalam mode terkunci, mereka tidak dapat menjelajahi situs lain atau membuka aplikasi lain. Jika peserta pelatihan keluar dari kuis, atau membuka tab lainnya, pengajar akan mendapat pemberitahuan melalui email. Selain itu dengan mengaktifkan mode terkunci beberapa ekstensi dan pintasan keyboard dinonaktifkan. Perlu diingat juga bahwa mode terkunci akan mengumpulkan alamat email peserta pelatihan dan membatasi kuis ke domain Anda saja. Untuk menggunakan mode terkunci, Anda memerlukan Akun G Suite for Education, Chromebook yang dikelola oleh lembaga pelatihan Anda untuk setiap peserta pelatihan, dan Chrome OS 75 atau versi yang lebih baru.

Berikut cara mengaktifkan mode terkunci:

1) Di Google Formulir, buka kuis.

2) Di bagian atas, klik Setelan lalu Kuis.

3) Centang kotak di samping "Aktifkan mode terkunci".

e. Memberi batasan waktu pada soal Pengaturan ini juga akan memberi peserta pelatihan suasana seperti di kelas dan memaksa peserta pelatihan untuk fokus pada soal.

Berikut caranya:

1) Di laman Google Form klik ikon Titik Tiga, lalu klik Add-on

2) Cari Formlimiter, instal
3) Klik izinkan untuk menampilkan script ke dalam akun google Anda

4) Setelah itu akan muncul proses pengaturan di mana Anda bisa memasukan batas waktu dan tanggal soal dikerjakan. Klik Save and Enable

5) Jika soal sudah mencapai waktu yang ditentukan, maka soal akan tertutup dengan sendirinya.

f. Memberi nilai pada kuis yang dikerjakan:

1) Di Google Formulir, buka kuis.

2) Di bagian atas, klik Tanggapan.

3) Klik Individu.

4) Untuk berpindah di antara individu, klik Sebelumnya atau Berikutnya.

5) Cari pertanyaan yang ingin Anda beri nilai, yaitu: Di kanan atas, masukkan jumlah poin yang dihasilkan oleh tanggapan. $D i$ bawah jawaban, klik tambahkan masukan.

6) Tulis masukan, lalu klik simpan.

7) Untuk menyimpan perubahan, di bagian bawah, klik Simpan.

g. Membagikan hasil melalui Google Form, Untuk mengirim hasil pengerjaan peserta pelatihan melalui email secara individu, caranya sebagai berikut:

1) Di Google Formulir, buka kuis.

2) Di bagian atas, klik Tanggapan lalu Individu.

3) Di bagian kanan atas tanggapan dengan alamat email yang tercatat, klik Rilis skor.

4) Centang kotak di samping orang yang ingin Anda kirimi email.

5) Klik Kirim email dan rilis.

\section{Menyusun Soal Menggunakan Quizizz}

Quizizz menjadi salah satu alternatif layanan pembuat soal dan kuis online yang mudah dan gratis. Dalam situasi pandemi Covid-19, pemberian soal dan kuis online menjadi salah satu alternatif dalam melaksanakan proses pembelajaran dari rumah bagi peserta pelatihan dan lembaga pelatihan.

Layaknya Google Form, Proprofs, Microsoft Forms, dan layanan 
lainnya, Quizizz merupakan sebuah web tool untuk membuat permainan kuis dan soal secara online yang dapat digunakan sebagai pembelajaran di kelas maupun di rumah secara daring. Kelebihannya, selain dapat digunakan secara gratis, pengoperasiannya pun sangat mudah, baik bagi pembuat kuis atau soal maupun bagi yang mengerjakan. Disamping itu, tampilannya sangat interaktif sehingga tidak akan membuat peserta pelatihan yang mengerjakan bosan.

Nilai yang diperoleh peserta pelatihan ditampilkan dalam bentuk poin. Poin dihitung tidak hanya berdasarkan benar atau salahnya jawaban saja tetapi seberapa cepat seorang peserta pelatihan menyelesaikan satu soal. Dan jumlah poin serta rangking poin peserta pelatihan akan ditampilkan setiap selesai mengerjakan satu soal. Sehingga dengan sistem poin ini akan menciptakan suasana kompetisi antar peserta pelatihan (live).

\section{a. Cara Daftar dan Login Quizizz}

Untuk pembuat soal harus login ke laman quizizz.com yang sebelumnya tentu harus mendaftar terlebih dahulu. Tetapi jangan khawatir, karena proses pendaftarannya (sign up) sangat mudah dan gratis.

Langkah-langkahnya adalah sebagai berikut:

1) Buka laman https://quizizz.com/

2) Klik tombol "Sign Up" atau "Daftar" di pojok kanan atas

3) Ada pilihan sign up dengan menggunakan akun google (Sign Up with Google) atau dengan email (memasukkan email)

4) Klik Next

5) Pilih peran sebagai Guru (as a teacher), peserta pelatihan (as a student), at a busines, atau sebagai orang tua (as aparent)

6) Isikan detail akun anda mulai nama depan, nama belakang, dan password (khusus jika sign up dengan menggunakan email)

7) Proses sign up, selesai

Selanjutnya, jika akan masuk ke akunnya tinggal mengklik tombol log in yang tersedia.

Pada halaman muka Quizizz akan ditampilkan beberapa menu diantaranya:
1) View Profil, untuk mengubah data profil diri.

2) Find Quiz, untuk mencari kuis dan soalsoal yang tersedia secara bebas dan gratis. Dimana kuis-kuis hasil pencarian tersebut dapat langsung dipergunakan atau diedit ulang.

3) My Quizzes, berisikan daftar kuis yang telah dibuat

4) Report, berisikan daftar kuis yang telah dikerjakan oleh peserta pelatihan beserta dengan statistiknya

5) Classes, jika ingin mengoordinir para peserta pelatihan dalam kelas

6) Collection, pembuat soal dapat membuat pengelompokkan soal (kuis) yang dibuatnya semisal berdasarkan kelas

7) Meme, pembuat soal dapat membuat meme-meme khusus yang dapat ditampilkan setiap kali peserta pelatihan selesai menjawab soal seperti meme yang menyatakan jawaban salah atau benar, pemberi semangat, dan lain-lain.

8) Setting, untuk pengaturan akun, pemilihan bahasa (tersedia Bahasa Indonesia), ganti password, hingga menghapus akun.

9) Log out, untuk keluar

\section{b. Cara Membuat Soal dan Kuis Online dengan Quizizz}

Ada dua pilihan untuk memulai membuat soal. Pertama dengan membuat soal dari awal (menu Create a new quiz) dan kedua dengan menggunakan dan memodifikasi kuis yang telah ada (menu Find a quiz). Mudahnya lagi, meskipun memilih membuat soal dari awal, nantinya pembuat soal dapat juga mengopy dari soal-soal yang telah ada (menu Teleport).

\section{1) Langkah-langkah membuat kuis (menu} Create a new quiz)

a) Klik menu "Create a new quiz"

b) Isikan Nama Kuis dan pilih subject atau label kuis

c) Klik Next

d) Klik menu "Add Quiz Image" untuk memasukkan cover kuis, bahasa antar muka kuis, kelas (usia) yang mengerjakan kuis, dan visibilitas kuis (publik atau privat) lalu Klik Simpan

e) Klik "New Question" untuk mulai membuat soal 
f) Pilih bentuk kuis yang terdiri pilihan ganda (multiple choice), kotak centang (checkbox), isian (fill in the blank), poll, atau open-ended

g) Tulis soal pada kolom yang tersedia

h) Tulis pilihan jawaban (jika menggunakan multiple choice atau checkbox)

i) Klik tanda centang (hingga berwarna hijau) pada pilihan jawaban yang benar

j) Pilih durasi mengerjakan (default-nya 30 detik)

k) Pertanyaan dapat disertakan gambar maupun suara dengan cara mengklik tombol media di sebelah kanan

1) Pilihan jawaban dapat berupa gambar dengan cara mengklik tombol media di sebelah kanan

m) Jika ingin menyertakan tulisan berupa simbol atau rumus matematika yang rumit, tersedia tombol khusus

n) Jika sudah klik save

o) Klik tombol "New Question" untuk membuat soal berikutnya

Jika ingin menyalin (copy) dari soal yang telah ada, caranya adalah:

a) klik tombol "Teleport"

b) Akan terbuka pencarian kuis sesuai dengan judul kuis yang dibuat. Jika kurang tepat dapat diubah sehingga menampilkan pencarian yang sesuai

c) Di bagian bawah terbagi menjadi dua bagian. Pada sebelah kanan adalah judul kuis-kuis yang sesuai dan di sebelah kiri adalah soal-soal kuis

d) Klik salah satu judul kuis yang tampil

e) Pada kolom sebelah kanan cari soal kuis yang cocok dan akan digunakan

f) Jika ketemu, arahkan kursor ke soal tersebut hingga muncul tombol ADD

g) Klik tombol $\mathrm{A} D D$ tersebut

h) Soal langsung tersalin ke kuis yang dibuat

i) Ulangi langkah ke-4 sampai dengan ke-7 di atas untuk menyalin soal lainnya

Kedua cara di atas (New Question dan Teleport) dapat sama-sama digunakan hingga soal kuis selesai dibuat. Klik "Done" untuk mengakhiri pembuatan soal. Akan tampil kuis yang telah dibuat tadi dengan beberapa menu seperti Save (untuk menyimpan kuis dalam menu Collections), Edit (untuk mengedit ulang kuis)

\section{2) Langkah-langkah menyalin kuis (menu Find a Quiz)}

Cara kedua membuat soal kuis dengan menggunakan Quizziz adalah dengan cara menyalin soal yang telah ada. Langkahlangkahnya adalah sebagai berikut:

a) Klik menu "Find a Quiz"

b) Ketikkan tema atau subjek soal kuis yang ingin dicari seperti "soal PKPPKA " lalu enter

c) Akan tampil berbagai kuis yang relevan dengan tema atau subjek yang dicari

d) Arahkan kursor pada judul masingmasing kuis dan disamping kanan akan ditampilkan isi soalnya

e) Klik pada judul soal yang diinginkan

f) Muncul tampilan soal

g) Klik "Edit" jika ingin mengedit ulang soal

h) Klik "Save" jika ingin menyimpan soal dalam "Collections" dan dapat menggunakan soal tersebut untuk peserta pelatihan Anda.

\section{c. Cara Membagikan Kuis di Quizizz}

Agar peserta pelatihan dapat mengerjakan kuis yang telah dibuat, maka kuis harus dibagikan. Cara membagikannya pun sangat mudah. Berikut langkahlangkahnya:

1) Buka kuis yang telah dibuat atau disalin. Soal kuis dapat dibuka melalui menu "My Quizizz" atau "Collections"

2) Setelah terbuka terdapat tiga menu utama "Play Live", "Assign HW", dan "Practice"

3) Practice (Latihan) digunakan untuk mencoba mengerjakan kuis yang dibuat (demo)

4) Play Live (Main Langsung) digunakan jika kuis dikerjakan saat itu juga secara klasikal.

5) Assign $H W$ (Jadikan PR) digunakan jika kuis dikerjakan secara bebas dalam waktu tertentu (hingga beberapa jam atau hari)

6) Setelah memilih Play Live (Main Langsung) atau Assign HW (Jadikan 
PR) lakukan beberapa pengaturan seperti deadline pengerjaan kuis (jika dijadikan PR), berapa kali seorang peserta pelatihan boleh mengerjakan, menampilkan jawaban yang benar di setiap akhir soal atau kuis, menunjukkan peringkat setiap peserta pelatihan, acak soal dan jawaban, hingga menampilkan meme di setiap jawaban peserta pelatihan.

7) Jika sudah klik "Continue"

8) Klik "Share Link" dan copy link yang tersedia. Peserta pelatihan dapat mengerjakan kuis dengan mengklik link tersebut

9) Atau dengan membagikan kode angka yang tersedia. Peserta pelatihan mengerjakan kuis dengan membuka laman https://quizizz.com/join lalu memasukkan kode angka tersebut

Ketika melakukan pengaturan sebagaimana pada poin ke-6 di atas, maka:

1) Peserta pelatihan harus mendaftar dan login ke akun Quizizz jika pembuat kuis:

a) Membatasi setiap peserta pelatihan hanya bisa mengerjakan 1-5 kali saja

b) Kuis hanya dikerjakan untuk satu kelas online yang sebelumnya telah dibuat

2) Peserta pelatihan tidak harus login, jika pembuat kuis:

a) Tidak membatasi kesempatan
peserta pelatihan dalam
mengerjakan (unlimited)
b) Tidak dipilihkan kelas online

Untuk melihat hasil pengerjaan kuis, tinggal masuk ke menu "Report". Di dalamnya tersaji laporan dari setiap kuis yang telah dibagikan. Satu kuis dapat dibagikan beberapa kali untuk kelas yang berbeda dengan laporan yang berbeda juga. Laporannya sangat lengkap, mulai dari jumlah jawaban yang benar atau salah, poin setiap peserta pelatihan, hingga detail jawaban dan waktu mengerjakan peserta pelatihan. Bahkan jika seorang peserta pelatihan mengerjakan lebih dari satu kali, maka masingmasing laporan dapat dilihat sehingga widyaiswara dapat memilih menggunakan jawaban yang mana.

\section{SIMPULAN DAN SARAN}

Adapun kesimpulan penelitian ini adalah : (1) Hal penting yang harus diperhatikan dalam menyusun kisi-kisi soal antara lain: a) Pemilihan sampel materi yang akan ditulis butir soalnya hendaknya dilakukan dengan mengacu pada tujuan pembelajaran atau kompetensi yang ingin dicapai; b) Jenis tes yang akan digunakan; dan c) Jenjang kemampuan berpikir yang ingin diuji; (2) Langkah-langkah untuk membantu mempermudah pengisian format kisi-kisi, antara lain: a) Siapkan format kisi-kisi dan buku materi; b) Tentukan kompetensi dasar dan indikator pembelajaran yang akan diukur; Tentukan pokok bahasan dan sub-pokok bahasan yang akan digunakan untuk mengukur ketercapaian indikator pembelajaran; c) Tentukan jumlah butir soal yang layak ditanyakan; d) Sebarkan jumlah butir soal tersebut per pokok bahasan; d) Distribusikan jumlah butir soal per pokok bahasan tersebut ke dalam sub-pokok bahasan sub-pokok bahasan; e) Distribusikan jumlah butir soal per sub-pokok bahasan tersebut ke dalam kolom-kolom proses berpikir dan tingkat kesukaran butir soal; (3) Pokok soal dapat dibuat dalam dua bentuk, yaitu dalam bentuk pernyataan tidak selesai atau dalam bentuk kalimat tanya. Jumlah alternatif jawaban yang dibuat biasanya empat atau lima. Semakin banyak alternatif jawaban yang dibuat, maka probabilitas peserta untuk menebak jawaban semakin kecil; (4) Menyusun soal pilihan ganda atau uraian mengacu pada aspek: a) materi, b) konstruksi, dan c) Bahasa. Pada aspek materi: a) Soal harus sesuai dengan indikator; b) Pengecoh harus bertungsi; dan c) Setiap soal harus mempunyai satu jawaban yang benar. Pada asepk Konstruksi: a) Pokok soal harus dirumuskan secara jelas dan tegas; b) Rumusan pokok soal dan pilihan jawaban harus merupakan pernyataan yang diperlukan saja; c) Pokok soal jangan memberi petunjuk ke arah jawaban yang benar; d) Pokok soal jangan mengandung pernyataan yang bersifat negatif ganda; e) Pilihan jawaban harus homogen dan logis ditinjau dari segi materi; f) Panjang rumusan pilihan jawaban harus relatif sama; g) Pilihan jawaban jangan mengandung pernyataan "Semua pilihan jawaban di atas salah"atau "Semua pilihan jawaban di atas benar"; h) Pilihan jawaban yang berbentuk angka atau waktu harus disusun berdasarkan urutan besar kecilnya nilai angka atau kronologis; i) Gambar, grafik, tabel, diagram, wacana, dan sejenisnya yang terdapat pada soal harus jelas dan berfungsi; j) Butir soal jangan bergantung pada jawaban soal sebelumnya. Pada aspek Bahasa/budaya: a) Setiap soal harus menggunakan bahasa yang sesuai dengan kaidah 
bahasa Indonesia; b) Bahasa yang digunakan harus komunikati; dan c) Pilihan jawaban jangan yang mengulang kata/frase yang bukan merupakan satu kesatuan pengertian; (5) Cara membuat soal kuis menggunakan Google Form, sebagai berikut: a) Buka Google Formulir, kemudian klik ikon Plus; b) Di bagian kanan atas, klik Setelan. c) Klik Kuis lalu Jadikan ini sebagai kuis; d) Opsional: Untuk mengumpulkan alamat email, klik Umum lalu kumpulkan alamat email; dan e) Klik Simpan; (6) Langkah-langkah membuat kuis (menu Create a new quiz): a) Klik menu "Create a new quiz"; b) Isikan Nama Kuis dan pilih subject atau label kuis; c) Klik Next; d) Klik menu "Add Quiz Image" untuk memasukkan cover kuis, bahasa antar muka kuis, kelas (usia) yang mengerjakan kuis, dan visibilitas kuis (publik atau privat) lalu Klik Simpan; d) Klik "New Question" untuk mulai membuat soal; e) Pilih bentuk kuis yang terdiri pilihan ganda (multiple choice), kotak centang (checkbox), isian (fill in the blank), poll, atau open-ended; f) Tulis soal pada kolom yang tersedia; g) Tulis pilihan jawaban (jika menggunakan multiple choice atau checkbox); h) Klik tanda centang (hingga berwarna hijau) pada pilihan jawaban yang benar; i) Pilih durasi mengerjakan (defaultnya 30 detik); j) Pertanyaan dapat disertakan gambar maupun suara dengan cara mengklik tombol media di sebelah kanan; k) Pilihan jawaban dapat berupa gambar dengan cara mengklik tombol media di sebelah kanan; 1) Jika ingin menyertakan tulisan berupa simbol atau rumus matematika yang rumit, tersedia tombol khusus; m) Jika sudah klik save; dan n) Klik tombol "New Question" untuk membuat soal berikutnya

Saran dari penelitian ini adalah: (1) Dibutuhkan pemahaman tentang kisi-kisi soal dan indikator soal sebelum menyusun soal berstandar; (2) Bahwa evaluasi akademik dalam bentuk soalsoal pilihan ganda atau soal-soal uraian hendaknya dibuat dengan valid dan reliabel, dan tentunya berstandar; (3) Soal-soal berstandar akan dihasilkan bila penyusunannya dilakukan dengan muatan standarisasi, sehingga dibutuhkan waktu dan tempat khusus untuk menyusun soal berstandar dimaksud; (4) Peran lembaga diklat diharapkan untuk memfasilitasi widyaiswara untuk menyusun soal berstandar yang akan diberikan pada pelatihan tertentu.

\section{DAFTAR RUJUKAN}

Admin Ayo Madrasah. 2020. Mudahnya Membuat Soal Kuis Online dengan Quizizz. Online.

Diakses:

https://www.ayomadrasah.id/2020/05/mem buat-soal-kuis-online-quizizz.html

Febriansyah. 2020. Cara Membuat Soal Online Menggunakan Google Forms. Online. Diakses: https://tirto.id/eKCW

Gronlund, N., E., \& Linn, R., L., (1990), Measurement and Evaluation in Teach-ing, New York, MacMillan. Pub. Company

Hopkins, C., D., \& Antes, R., L., (1990), Classroom Measurement and Evalua- tion, Illinois, F.E. Peacock Publishers. Inc.

Nitko, A., J., (1983), Educational Test and Measurement: an Introduction, New York, Harcourt Brace Jovanovich, Inc.

Panduan Pengembangan Penulisan Soal, Dirjen Dikti, Kementerian Diknas, 2010

Panduan Penulisan Butir Soal Depdiknas, Dirjen Dikdasmen, 2008

Peraturan Kepala LAN Nomor 15 Tahun 2019 tentang Pelatihan Kepemimpinan Pengawas.

Peraturan Kepala LAN Nomor 16 Tahun 2019 tentang Pelatihan Kepemimpinan Administrator.

Pramana,Y.A., Supraptono, E., \& Pribadi, F.S. 2013. Aplikasi Microsoft Office Excel 2010 Untuk Menganalisis Butir Soal Pilihan Ganda. Jurnal Teknik Elektro Vol. 5 No. 2 Juli - Desember 2013, hal. 93-95.

Syaodih, N. (2009). Metode penelitian pendidikan. PT. Remaja Rosdakarya.

Zainul, A dan Nasution, N. 1997. Penilaian Hasil Belajar. Jakarta: Departemen Pendidikan dan Kebudayaan.

Zed, M. (2003). Metode penelitian kepustakaan. Yayasan Obor Indonesia. 
Tahir. Menyusun Soal PKP-PKA Berstandar Adalah Keniscayaan ... 